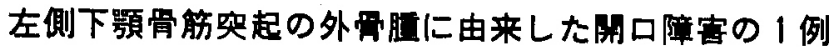

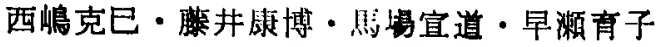

\section{Limited opening of the mouth caused by exostosis of the left coronoid process of the mandible : report of a case}

\author{
Katsumi NISHIJIMA - Yasuhiro FUJII = Norimichi BABA - Ikuko HAYASE
}

\section{楮言}

口腔外科領域において，しばしば遭退する症状の一つ

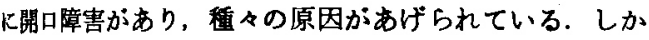
し筋突起に発生した骨連による開口障害はきわめてまれ である.

骨軟骨性外骨埂の発生頻度は，全身的には比較的多い

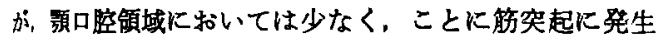
ナることはまれといわれている。

このたび私達は，左側下頻骨筋突起に発生した骨軟骨 珄外骨腫により開口障害をきたした稀有なる症例を経呀 したので，その概要を報告する。

$$
\text { 症例 }
$$

患者:—、男性，25才，

初診: 昭和 44 年 9 月回.

主訴: 開口障害ならびに開口時左側額関節部雑音.

家族歴：特記事項なし.

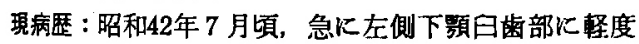
の自発痛之開口時左側须関節部の疼痛をきたした，某州 科医にて 8 智菌周囲炎の診断にて $\sqrt{8}$ 抜去するる，左側影 閶節部疼痛軽隇せず，開口障害著明となった，昭和 42 年 9月より某大学口膑外科沶よび整形外科などを受診，関 解卧内注射, 理学療法, 薬物療法を受けるる，開口障害 悎棈せす，昭和 43 年 9 月頃より開口時雑音を伴うよ5 になり当科来院.

現症

全身所見：体格中等度，栄養佳良、胸部 X線像， E. K.G.，尿所見等異常なし. 血圧 $122 \sim 66 \mathrm{mmHg}$.

血液所見: 血色素量 $13.9 \mathrm{~g} / \mathrm{d} l$, 赤血球数 $498 \times 10^{4} /$ $\mathrm{cmm}$ ，色素指数 0.87 ，中性好性白血球70\%（杆状白血球

岡山大学医学部口腔外科学教室（主任 : 西㛛克已教授) Department of Oral Surgery, Medical School, Okayama University (Chief : Prof. Katsumi Nishijima)

受付 昭和47年 6 月22日
$0 \%$ ，分葉核白血球 $2 \%$ ，酸好性白血球 $0 \%$ 塩基好性 白血球 $2 \%$ ，路球 $3 \%$, リン八球 $25 \%$, 栓球数 $26.89 \times$

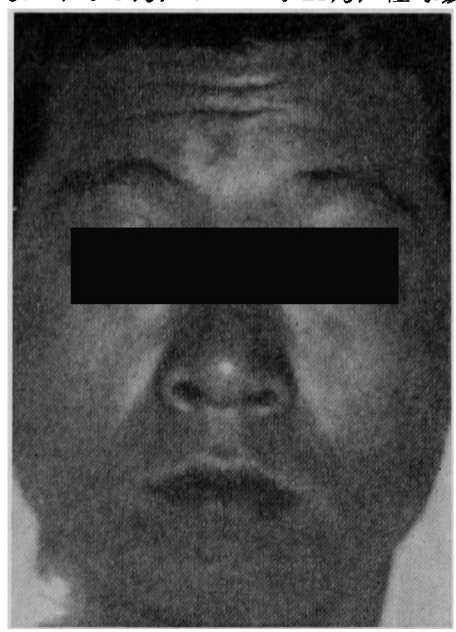

(a)

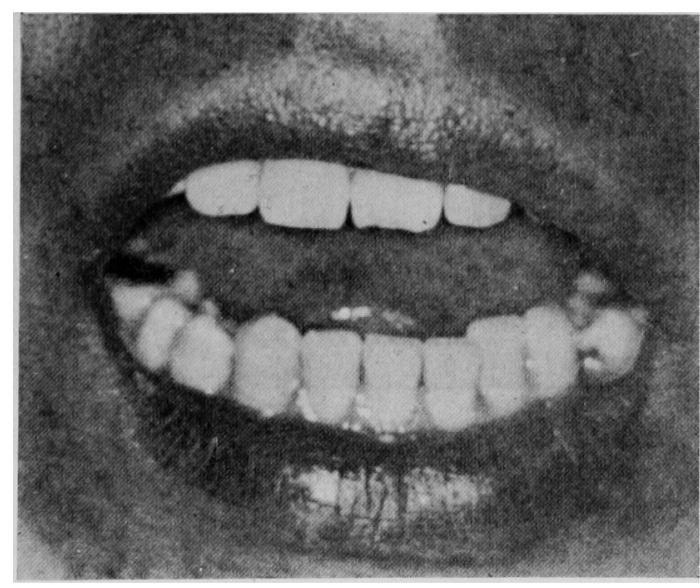

(b)

写真 1 初診時䫠貌 (a) 最大開口時 $(b)$ 
$104 / \mathrm{cmm}$ ，比血㭙間3.5分，凝测湆間9.5分.

血济化学模查: $\mathrm{Na} 138 \mathrm{mEq} / l, \mathrm{~K} 4.5 \mathrm{mEq} / l, \mathrm{Ca} 9.8$ $\mathrm{mEq} / l$, Al-P-ase 1.6 Bessey-u, ワ氏父他飡性，GOT $13 \mathrm{u}$, 霰反底 : $\mathrm{ZnSO}_{4} 7 \mathrm{u}$, Thymol $2 \mathrm{u}, \mathrm{CCLF}(-)$, Co 6 .

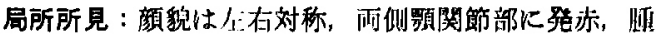

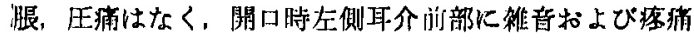

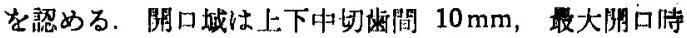

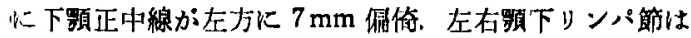
ともに触れず。

口腔内所見: の特記すべき病変なし.

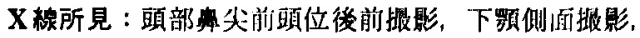

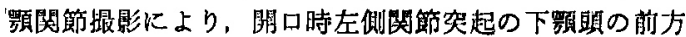
移動が制限され，左側下䫟骨威節突起は右側飞比し短少 で，下䫑頭後前の变形がみられ，外形不明瞭.

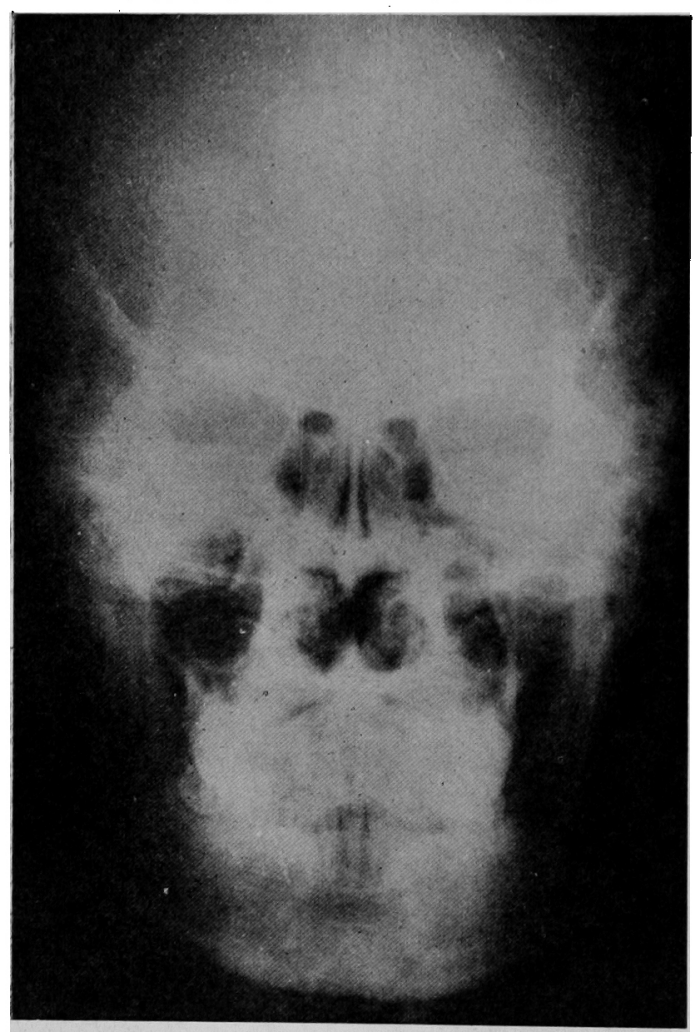

写重 2 術前 $X$ 線写真 (頭部啳前撮影)

臨床診断：左側顋関節強直症

\section{処道ならびに経過}

昭和44年11月 日日顎関節授動手術施行，すなわら経鼻 挿管， G-O-F 全身麻酔下に，左側耳介前縁に沿って皮

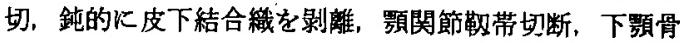
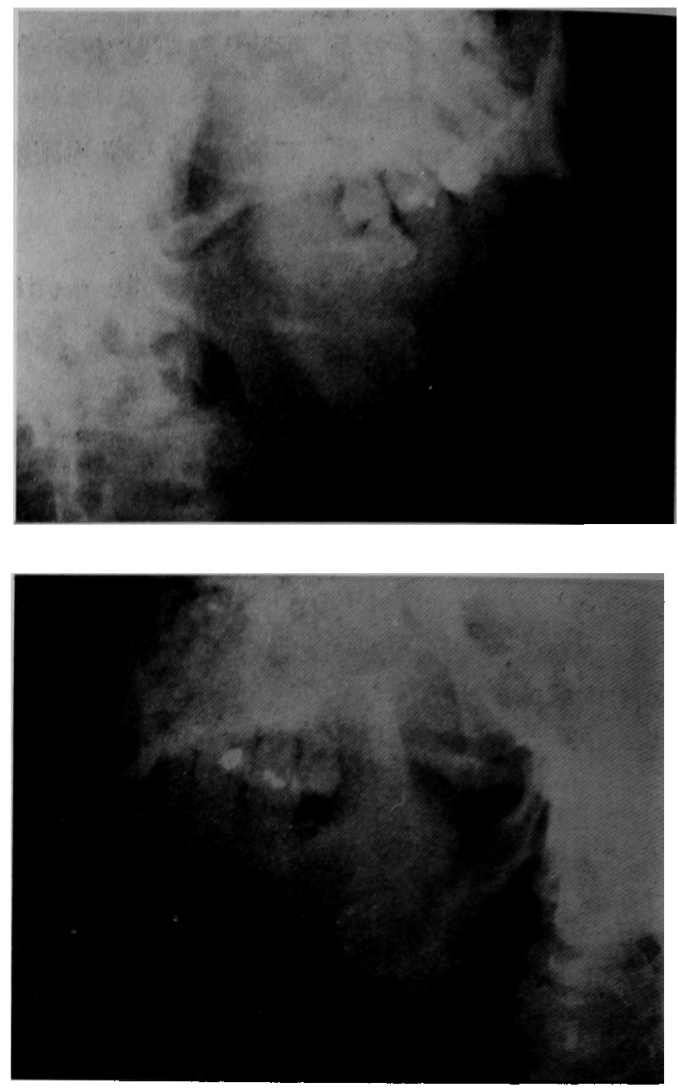

b

写重 3 術前X楾写真 (下方斜位撮影) (a : 右㽗, b : 左側)

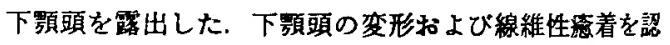
めたので，下頻龭部を骨！ミにて離断し，下影頭を摘出， 左側腹部より皮虚弁 $(8 \times 4 \mathrm{~cm})$ を切除，表層を内僋

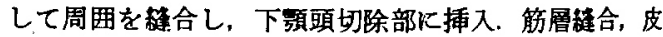
膚程合を行ない，手術を釉えた。

しかし術後も開口状態は改善されなかったため，X線 断層撮影，側頍斜位上方向撮影，眼㝛・関節方向撮影の 結果, 左側下䫑骨笳突起上端前椂上り前方に有茥性，扇 形に突出した境界明瞭な拇指頭大のX線不透過像を認め た、前䋧は上額結節部を王迫し，同部に㖟収像がみられ た.

以上の所見より，左側下類骨筋突起部の骨腫の题いの 下に，再度昭和44年11月⿴日手術を施行した。

前回同様全身麻酔下に，口腔内より左側筋突起相当煩 粘膜に切開線を入れ，㬳突起基部を露出，骨ノミにて筋

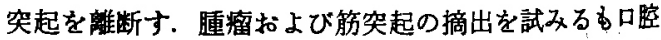
内よりの摘出は不可能であった．術後13日，開口域は上 下中切歯間で $25 \mathrm{~mm}$

昭和 44 年12月日日，全身麻酔下，頓骨弓上緑汇沿亏皮 

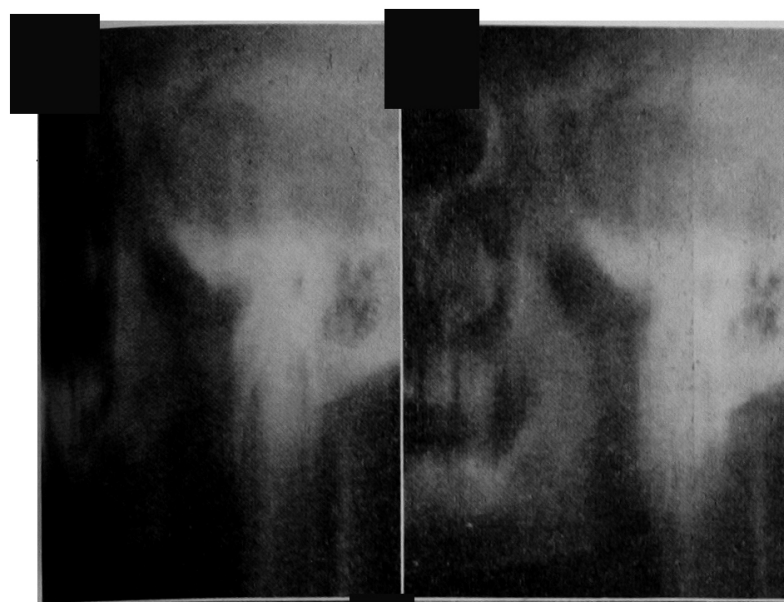

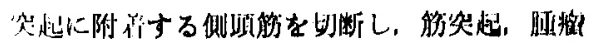

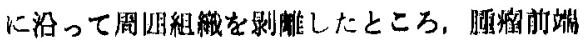

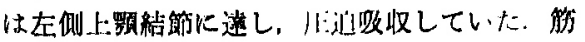

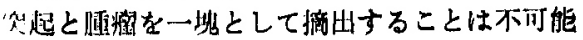

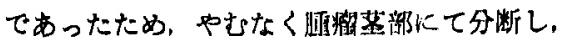

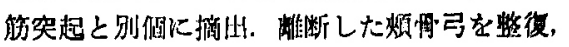

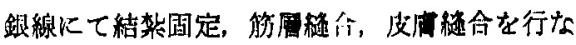
a い手術を格之た。

術後数日間, 左煩部, 侧頭部に鿭温性嗹腿, 発赤をみるも，6日目には汪とんと消退。网口 域住 6 日目 $23 \mathrm{~mm}, 13$ 日目 $29 \mathrm{~mm}$ 改源され た.

昭和45作 5 月日日，局所暗醉下に煩骨弓部銀 線除上を行なった。

摘出術後 7 カ月, 開口域 $40 \mathrm{~mm}$, 最大開口時 下靧正中の左方 $5 \mathrm{~mm}$ 偏倚を認めたが，なんら 機能的障害は認められなかった。

摘出物肉眼所見: $22 \times 32 \times 20 \mathrm{~mm}$ の大きさ の骨様組織で, 前, 内, 外，上方が軟骨様硬， 白色板状物にて被覆され，後方は筋突起尖端前 緑に移行していた，矢状断面は筋突起移行部よ り放射状に伸展する骨梁がるられ, 白色板状物 は骨様構造とは境界明嘹, 軟骨様であった。

病理組織学的所見：腫瘤は良く発達した骨梁 の形成かみられ，その表面にはかなり厚い軟骨 㬝があり，さらにその表面に結合織性の被覆が みられた，軟骨層には大型の軟骨細胞が軟骨窝 の中に入り，一定方向を保って配列，正常の骨 端線に打けると同様の化骨機転を示し，良く分 化した海綿骨を形成していた。

病理組織診断：骨軟骨性外骨尰（osteocarti、 lagenous Exostosis)

\section{総括ならびに考案}

開口障害の原因としては関節性，筋性，痸痕 性, 神経性，炎症性, 腫湯性, 外傷性儿上るる のなどが挙げられる.

Thoma $(1963)^{18)}$ は顎関節そのものに関係し ない，いわゆる偽歌関節強直症 False ankylosis として
1）筋の感染比上る筋性顎関節強直症
2）筋の萎縮または線維化
3）テタニーまたは破傷風によるるの
4) ノイローゼ, てんかんによる神経性のる

写真 4 a) 左側断風撮影（左：閉口時，右：開口時）

b) 右㑡断圈撮影（左：閉口時，右：開口時） c) 頭部軸方向撮影

5）ヒステリー性影関節強直症

妇を施し，鈍的に頓骨弓を十分露出し，筇突起を被う煩 骨弓䄪 $30 \mathrm{~mm}$ にわたり切断. 前回離断した筋突起は容 易飞露出されたが，腫瘤は煩骨内侧に陥入していた．筋
を挙げ，さらに機峨的ブロック (Mechanical block) として，下顎骨笳突起の外骨瘇，肥大，骨腫和上び骨軟 骨腫の報告について述べている，下須骨筋突起飞発生し 


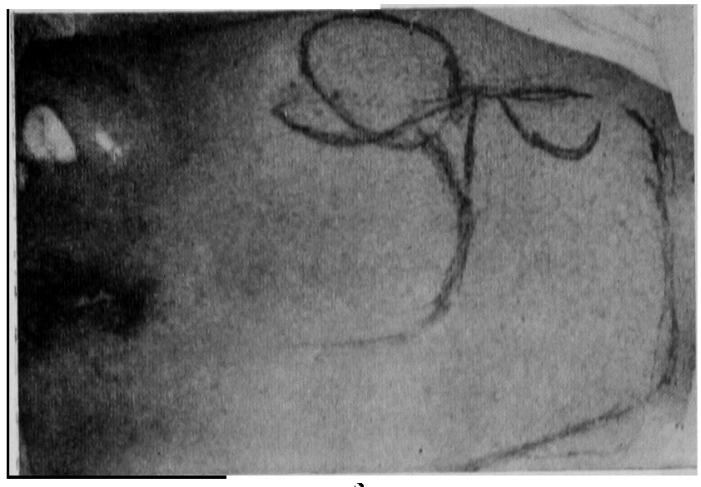

a

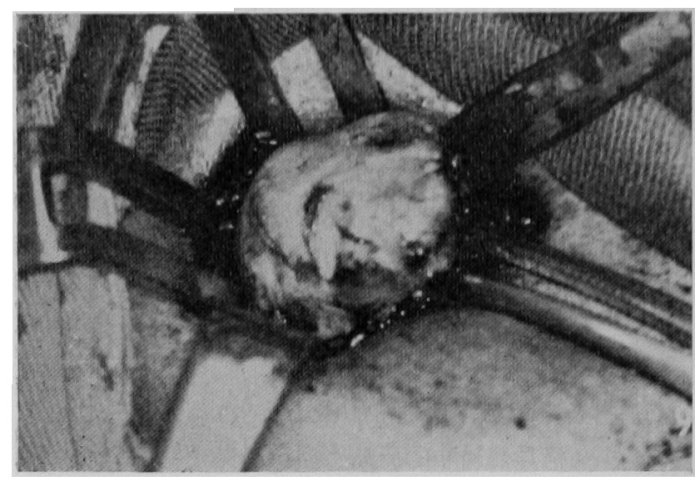

b

军真 5 術前㮔瘤部位 (a) 腫獈摘出時 $(b)$

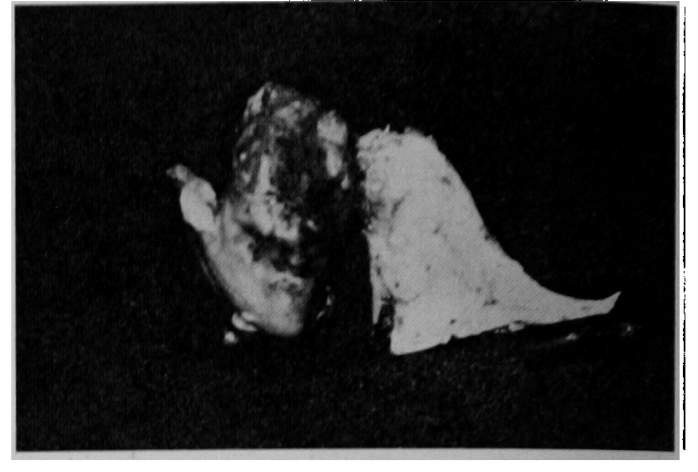

$\mathbf{a}$

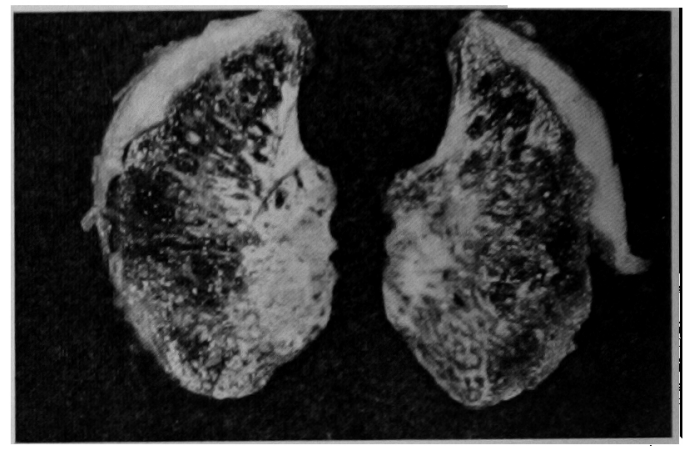

b

写奥 6 摘出物所見 (a)

分割面所見 (b)

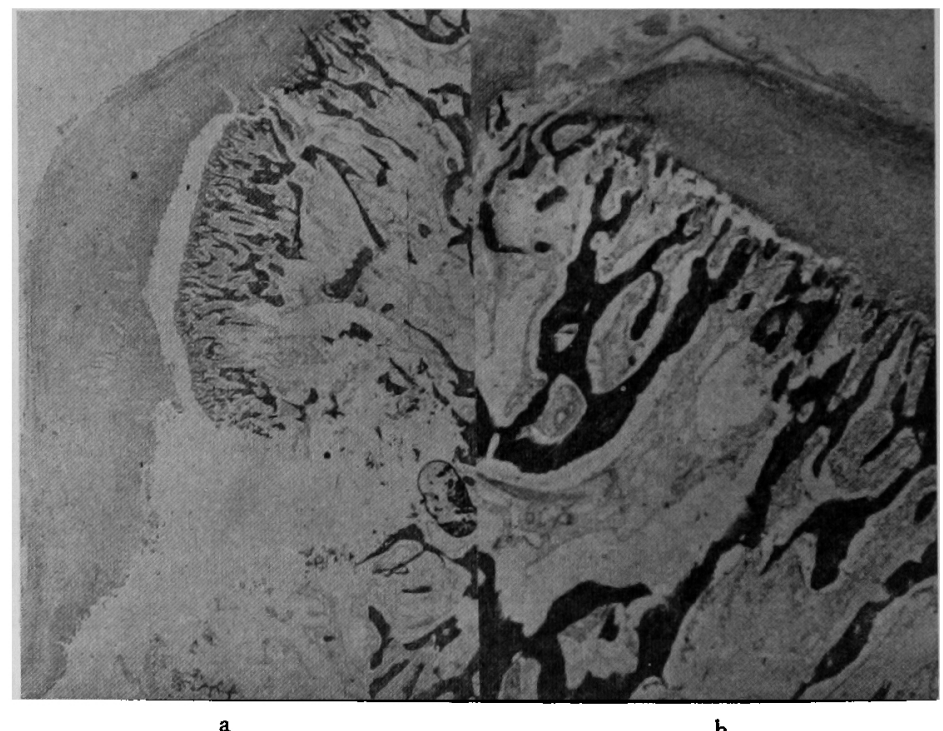

写真 7 病理組㮽写真 (H.E 染色)

弱桩大 $(\times 3.4)(a)$, 強抬大 $(x 7.5)(b)$ 


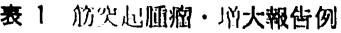

\begin{tabular}{|c|c|c|c|c|c|c|c|c|c|c|c|c|}
\hline & 報 告 者 & 乵告年度 & 性 & 年令 & 部位 & 病狸組粘胗䉼 & 瘦状自 & 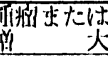 & & 切部 & 位 & 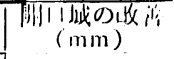 \\
\hline 1 & $\begin{array}{l}\text { Shackelford \& } \\
\text { Brown }\end{array}$ & 1943 & ô & 15 & 左 & Osteochondroma & $3 \mathrm{Y}$ & 股 梅 & 烦 & 情防 & & 12 一泾沵 \\
\hline 2 & " & $"$ & $\hat{o}$ & 19 & 右 & $"$ & $2 \mathrm{Y}$ & $"$ & & $"$ & & 10-正敞 \\
\hline 3 & Brandt & 1943 & ? & 37 & 右 & Exostosis & $5 Y$ & 不 明 & 不 & & 明 & 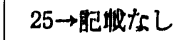 \\
\hline 4 & $\begin{array}{l}\text { Shackelford \& } \\
\text { Brown }\end{array}$ & 1949 & $\hat{o}$ & 38 & 右 & Osteochondroma & $5 Y$ & 胍龵 & 㤕 & 情 ij & 㑡 & 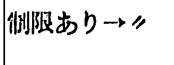 \\
\hline 5 & $"$ & " & o & 51 & 左 & Osteoma & $2 \mathrm{Y}$ & $"$ & & $"$ & & $" \quad \rightarrow "$ \\
\hline 16 & Brailsford & 1952 & $\delta$ & 24 & 応 & Osteochondroma & $1 Y$ & $"$ & 不 & & 明 & $12 \rightarrow 25$ \\
\hline 7 & Holmes & 1956 & $\hat{o}$ & 30 & 阿 & " & $16 \mathrm{Y}$ & $"$ & & $"$ & & $7 \rightarrow 28$ \\
\hline 8 & $"$ & $"$ & $\delta$ & 36 & 左 & " & $22 \mathrm{Y}$ & $"$ & & $"$ & & $8 \rightarrow 18$ \\
\hline 9 & Van Zile \& Johnson & 1957 & $\delta$ & 30 & 邽 & Exostosis & $16 \mathrm{Y}$ & 增大 & & $"$ & & 7ー眍线なし \\
\hline 10 & Levine et al. & 1957 & q & 73 & 左 & Osteochondroma & $30 Y$ & 峏疽 & & $"$ & & $0.6 \rightarrow 20$ \\
\hline 11 & Dingman \& Natvig & 1957 & o & 27 & 右 & $"$ & $4 \mathrm{M}$ & $"$ & 口 & 腔 & 内 & $8 \rightarrow 25$ \\
\hline 12 & Antoni et al. & 1958 & $\delta$ & 29 & 左 & " & $5 Y$ & $"$ & & $"$ & & 正常 $\rightarrow$ 正常 \\
\hline 13 & Shira \& Lister & 1958 & $\delta$ & 14 & 両 & $\begin{array}{l}\text { Developmental } \\
\text { anomaly }\end{array}$ & $9 \mathrm{M}$ & 增 大 & 顎 & 下 & 部 & $8 \rightarrow 42$ \\
\hline 14 & Lewars & 1959 & o & 15 & 右 & Osteoma & $9 \mathrm{M}$ & 瓜 瘤 & 側 & 頭 & 部 & $3 \rightarrow 12$ \\
\hline 15 & Lebo & 1961 & $\delta$ & 18 & 左 & Osteochondroma & $5 Y$ & " & 煩 & 骨 弓 & 部 & $14 \rightarrow 29$ \\
\hline 16 & Mohnac & 1962 & $\delta$ & 18 & 両 & " & $4 Y$ & 增 大 & 顎 & 下 & 部 & $18 \rightarrow 35$ \\
\hline 17 & Rowe & 1963 & o & 15 & " & $\begin{array}{l}\text { Developmental } \\
\text { hyperplasia }\end{array}$ & $3 Y$ & " & 口 & 腔 & 内 & $15 \rightarrow 35$ \\
\hline 18 & " & " & o & 15 & $"$ & " & $2 Y$ & $"$ & 不 & & 明 & $10 \rightarrow 10$ \\
\hline 19 & Lyon \& Sarnat & 1963 & ô & 27 & " & Enlargement & $14 Y$ & $"$ & ロ & 腔 & 内 & $11 \rightarrow 35$ \\
\hline 20 & Fitzpatrick & 1970 & ô & 27 & $"$ & " & $9 \mathrm{Y}$ & $"$ & 口腔 & 内, 煩骨 & 弓部 & $5 \rightarrow 40$ \\
\hline
\end{tabular}

た腫瘤および筋突起の増大した症例の報告は，われわれ が涉椫した限りでは表 1 に示すごとくである.

下颗骨筋突起の腫瘤による頻関節強直症の報告は, Shackelford \& Brown (1943) ${ }^{16)}(1949)^{16)}$, Brandt

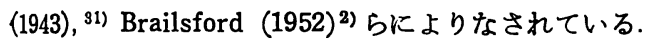

また Van Zile \& Johnson (1957) ${ }^{19}$, Shira \& Lister (1958) ${ }^{17)}$ ，最近では Fitzpatrick (1970) 5) らの筋突起增 大による䪽関節強直症の報告がみられる.

以上の報告による20例の病理組織学的診断では骨軟骨 腫11例，筋突起の増大 2 例, 外骨症 2 例, 骨腫 2 例, 筋 突起の過剩発育および肥大 3 例であった.

われわれの症例の組織診断では骨軟骨性外骨腫 (osteocartilagenous Exostosis) であったが, この名称 は日本整形外科学会の骨腫瘍分類 ${ }^{8)}$ に基ずいている.

伊丹 (1966) ${ }^{8)}$ によると骨軟骨性外骨腫の組織所見とし ては, 腫瘤は表面より線維層, 硝子軟骨層, 石灰化軟骨層, さらにその下部の海綿骨様構造がみられるとしている.

Weinmann \& Sicher (1947) ${ }^{20)}$ によると骨軟骨腫は 腫瘤表層より結合織, 線維性軟骨, 石灰化軟骨, 正常骨 が層状に配列したもの，あるいは軟骨，類軟骨組織が不 规則に入り込んだるのなどが存在するとしている.

骨腯湯の分類は，その組織像が部位により多様であり， 診断る困難であり，その名称も統一されていない。

われわれの調查した報告例において，骨軟骨腫と記載 のあった症例は，その組織所見よりほぼわれわれの症例 と本態は同じであると考えられた.
報告例の骨軟骨腫以外の症例についてみると, 筋突起 の增大とした Shira \& Lister $(1958)^{17)}$, Lyon \& Sarnat $(1963)^{12)}$, Fitzpatrick $(1970)^{5)}$ の症例では, 一 部外側面に軟骨様組織がみられたとし，本症例との区別 は明らかではない。

一方，骨腫と診断された Shackelford \& Brown

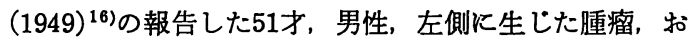
よび両側笳突起に発生した外骨症と診断されたVan Zile \& Johnson (1957) ${ }^{19)}$ の報告した症例においては軟 骨様組織はみられなく，また Rowe (1963) ${ }^{14)}$ の両側筋 突起の増大した 2 症例も単なる筋突起の增大であり, 新 生物とは認められず，本症例とは異なるものと思われた。

そこで報告例のうち病理組織診断がわれわれの症例骨 軟骨性外骨腫と同しくく，片側性，骨軟骨腫であった 9 例 について検討を加える.

すなわち性別では男性 8 例，女性 1 例と男性に多く， 年令では10才代 3 例, 20才代 3 例, 30才代 2 例, 70才代 1 例, 最年少15才, 最年長73才であり, 小数例ではある が大部分が10〜30才代にみられている.

また最終診断病院受診時の主訴では開口障害 6 例, 開 口時雑音 2 例, 不明 1 例であった. 自覚症状発現より受 診までの期間では 1 年までのもの 2 例, 2 年ないし 5 年 5 例, 20 年ないし 30 年 2 例であり, $2 \sim 5$ 年の間経過し たものが多かった. 筋突起についての左右差では左 6 例, 右 3 例であった.

全身他部に拈ける本症の発現頻度は, 伊丹采によると 
全骨婳湯中12\%であり，性则でホ少 3 刘女 2 の比称，発 見年令は10〜20才頃としている.

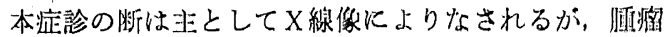
の部位，大きさ，形状を恋知するた特殊拫影江に上る 注意深い恰查が必要である，嘼部後前报影，侧力搌影，

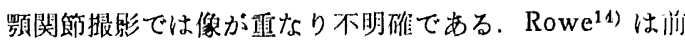

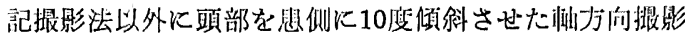
により，片侧珄のものは明確となり，さらに断盗掫影， パントモグラフをも推奖している.

烸床所見の特敞として Shira \& Lister ${ }^{17)}$ (

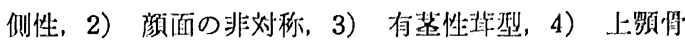
の圧迫吸収を等げている。 また Rowe ${ }^{14)}$ は片侧性增大

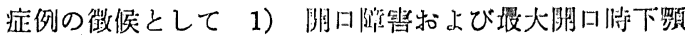

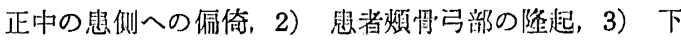

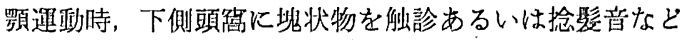
の求項を記载している。ささらに雨侧性増大においては， あらゆる方向への下靧の運動制限を特徵としている。す

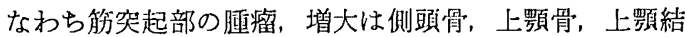
節，頓骨弓に上り囲まれた部位に拡大，あるいは周围の 骨北衡突することにより，上下方向の運釛障害のみなら ず，患側への下罰側方運動制限を引き起し，開口不能さ らには頓骨弓部の变形, 顔面の左右非対称を発現するも のである.

治療法としては，外科的飞切除，摘出する以外飞方法 はない，手術に拈ける皮切部位では煩骨弓部 4 例，口腔 内 2 例，不明 3 例であった．Rowe ${ }^{14)}$ は口腔内上り骨ハ 一飞て筋突起基部を切断し, Shackelford \& Brown ${ }^{16)}$ は煩骨弓部の皮切より煩骨弓を切断，腫瘤を摘出し，再 び整復している．またこの際，顔面神経の損偤に注意す る必要があると述べている.

開口域については上下切雬間で，術前の平均 $9 \mathrm{~mm}$, 術後計涀した 5 例についての平均は $23 \mathrm{~mm}$ であった。

最後に本疾患の病因についてみると，Geschicker \& Copeland (1949) ${ }^{6)}$ は軟骨腫場は主として䩓帯が骨膜を 介さず，直接骨に付着する部分に発現すると述べ，Shackelford \& Brown ${ }^{16)}$ は既往疾患に傷がないこと, 勒帯付 着部に発生していることより，筋突起部の骨膜のない部 位に前軟骨芽細胞が引き出され，時とともに骨軟骨腫と なったと述べている.一方, Weinmann \& Sicher ${ }^{20)}$ とよ ると胎生期の筋突起飞は cartilagenous growth center が存在し, 筋突起を形成し, この center 自体は消隇する としている. Shira \& Lister ${ }^{17)}$ は両側性の筋突起增大 例の成因としてこの center の遺残より增大すると述べ ている. Lyon \& Sarnat ${ }^{12)}$ は筋突起の变化は，側頭朌 の铄引の結果であり, また他の可能性として上記 center の残存も考劣られるとしている。 また伊丹息によると 骨軟骨性外骨腫の成因が骨端発育軟骨部が骨膜内に残っ た遗残軟骨より発生する説と，同部の先天あるいは後天 的因子による異常発育であるといら説をあげている.
以上の上うに成因については明らかでないが，両側性 伤突起增大の成因としては，成長中心の残遗説，また片

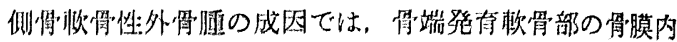

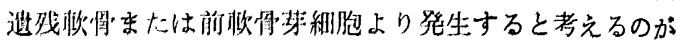
妥当であろう。

\section{結論}

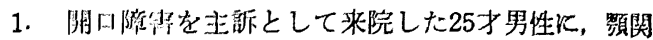

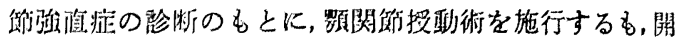

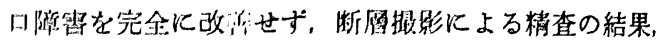
併突起部の罢州を発見した。

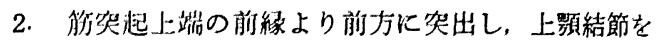

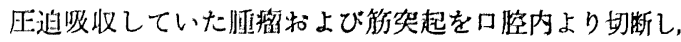
煩骨局部上り摘出した，その結果開口障害を完全飞治慜 せしめた。

3. 摘出物の病理組䄉颜断は骨軟骨性外骨腫 (osteocartilagenous Exostosis) であった.

4. 開口障害の㭧者に扣いては笳突起部の精查の必要 性を示唆する興味ある症例であった。

稿を終るに臨み，御校圆を睗わった话包義男前教授ならび 病理組䑾㭘査に朢篤な御指遒を助わった本学第 2 病理学教室小 川勝士数授に感謝の意を表します。

（本論文の要旨は昭和45年 4 月第 24 回日本口沿科学会総会に おいて発袋した）

\section{文献}

1) Antoni, A. A., Brown, A. \& Johnson, J. H. : Osteochondroma of the coronoid process of the mandible. J Oral Surg $16: 514-5171958$.

2) Brailsford, J.F. : An unusual osteochondroma from the coronoid process of the mandible. Brit J Radiol $25: 555-5561952$.

3) Brandt. K. : Defor mation congenitale de I'apophyse coronoid du maxillaire inferieur. Acta Orthop Scand 14 : 219-224 1943.

4) Dingman, R. O. \& Natvig, P. : Reduced mandibular motion due to osteochondroma of the coronoid process of the mandible. Amer J Surg 94:907-910. 1957.

5) Fitzpatrick, B. N. : Bilateral hyperplasia of the mandibular coronoid process. Oral Surg Oral Med \& Oral Path 29 : 184-190 1970.

6) Geschickter, C.F. \& Copeland, M. M. : Tumors of bone. ed 3, Philadelphia, J B Lippincott Co, 1949.

7) Holmes, F. H. : Mandibular block by osteochond roma of coronoid process. Radiology $67: 578-581$ 1956.

8）伊丹康人：骨腫痬. 第 1 版, 医学書院, 東京, p. 5, 45641966.

9) Lebo, C. P. : Osteochondroma of the mandibular coronoid process. Laryngoscope $71: 814-8221961$.

10) Levine, M.H., Chessen, J. \& McCarthy, W.D. : Osteochondroma of the coronoid process of the mandible. New England J Med 257 : 374-376 1957.

11) Lewars, P.H.D. : Osteoma of the mandible. Brit J Plast Surg $12:$ 277-283 1959.

12) Lyon, L.Z. \& Sarnat, B. G. : Limited opening of 
the mouth caused by enlarged coronoid process. J Amer Dent Ass 67 : 644-650 1963.

13) Mohnac, A. M. : Bilateral coronoid ostcochondroma, J Oral Surg Anesth $20: 500-5061962$.

14) Rowe, N. L. : Bilateral developmental hyperplasia of the mandibular coronoid process. Brit J Oral Surg $1:$ : 90-104 1963.

15) Shackelford, R. T. \& Brown, W. H. : Osteochondroma of the coronoid process of the mandible. Surg Gynec \& Obst 77 : 51-54 1943.

16) Shackelford, R. T. \& Brown, W. H. : Restricted jaw motion due to osteochondroma of the coronoid process. J Bone Joint Surg 31 A : 107 : 1141949.

17) Shira, R. B. \& Lister, R. L. : Limited mandibular movements due to enlargement of the coronoid processes. J OralSurg $16: 183-1911958$,

18) Thoma, K.H. : Oral Surgery. ed 4, St Louis, The C V Mosby Co, p.606 1963.

19) Van Zile W.N. \& Johnson, W.B. : Bilateral coronoid process exostosis simulating partial ankylosis of the temporomandibular joint. J Oral Surg 15 : 72-77 1957.

20) Weinmann, J.P. \& Sicher, H. : Bone and bones. St Louis, The C V Mosby Co, p.386 1947. 